London Clinical Society. - The Fifth Annual MacAlister Lecture will be delivered at The London Temperance Hospital on Tuesday, June 24, 1930, at 9 p.m., by Sir Robert Armstrong-Jones, C.B.E., D.Sc., M.D., F.R.C.P., D.L., Lord Chancellor's Visitor in Lunacy. Subject: "The Evolution of the Human Mind" (illustrated by lantern slides).

All students, medical practitioners and their friends are cordially invited to be present.

\title{
STUDY TOURS AND POST-GRADUATE EDUCATION SUB-COMMITTEE.
}

Visit of Dutch Psychiatrists to England, September, 1929.

During the hospitable and instructive visit to Dutch mental hospitals which members of this Association paid in October, 1928, a reciprocal tour was suggested by Dr. Engelhart, of Utrecht. Early the following year a provisional programme was submitted to the Dutch Association of Asylum Physicians. The Medical Superintendents of all the institutions in the programme, however, by their ready sanction and hearty invitation promptly divested the programme of any provisional character, and their cordiality will be remembered by our colleagues from the Netherlands with a tender regard for many years to come.

They arrived on Monday night, September 9 , at Liverpool Street, and spent the first three nights in a modern Bloomsbury building. One was glad that their subsequent quarters formed a pleasant though varied contrast, and afforded more characteristic impressions of British hostelries.

On Tuesday morning the first instruction to "Steve," the driver of our coach, was to call at the box office of a certain theatre. This diversion from the strict path of psychiatry cost us the ill-repute of reaching Horton a quarter of an hour behind the scheduled time. This did not, however, lessen the welcome which Dr. J. R. Lord and his Staff gave our visitors in the Admission Hospital, where they saw the most recent conceptions in hospital design, both completed and in building. One heard urgent but whispered inquiries as to the nature of Plombieres' fame and ritual.

Then we visited the wards of earlier construction, where the durability and costly appearance of the furniture and equipment were quickly observed, and no less so the leisure of the patients, who were making the most of a fine day of late summer in the gardens; leisure, in Holland, being of a somewhat restricted character.

We saw the provision made for various special medical and surgical departments of treatment, for gynæcology, actinotherapy and X-rays, for occupational therapy, remedial exercises and massage, each of which is directed by a visitin consultant or resident expert. We heard, too, of the team-work among the medical officers, and had ample evidence of the prevailing hospital atmosphere. Indeed, one could quote lessons from Horton which general hospitals might with advantage apply to their own administration. Among the special departments, the Malarial Research and Treatment Centre greatly appealed to our visitors in the completeness of its equipment and achievement.

Mr. Greenwood, the Chairman of the Hospital Committee, was so good as to come out to Epsom to meet the visitors, and to join them in a lunch, the excellence of which, had they but known at 8 a.m., would have restrained them from essaying the " English breakfast."

An important part of the visit was that given to the accommodation and training of nurses; we saw the recently erected Home, a building of really pleasing appearance, convenient and comfortable, where no small requirement of its residents had been forgotten. Their School of Instruction has well equipped quarters of its own, and it was evident to the visitors that nothing was omitted in that essential hospital duty, the training of the nurse.

We desired to spend a much longer time than was available in the Pathological section, but received a summons to the lawn, which proved both attractive and refreshing. And so we came to the close of what our colleagues from Holland regarded as a day of memorable first impressions.

A variety theatre had been selected as a place of instruction in our own tongue after dinner, but the velocity of subtle and oblique utterance proved a double

LXXVI. 
obstacle where the simplicity of wit alone had been anticipated, for it was necessary both to translate the more local idiom and to diagnose the wit.

Dr. Mapother had not yet returned from a foreign visit, but had very kindly made arrangements for Dr. Harris and his colleagues to show our party the Maudsley Hospital on Wednesday morning. Having introduced the members to Dr. Harris, I had to leave shortly afterwards. Calling after lunch to accompany them to Bethlem, I found them in no haste to leave the hospitable table where they had been the guests of the Medical Superintendent. This hospital with its scientific research, clinical and pathological, and its "open" wards, was full of interest for our colleagues who, in Holland, have succeeded in extending so widely the same principle and practice. There any suitable premises may by Royal Decree be declared an asylum of the open-door type, where patients are received without certificates of any kind, and are at liberty to take their discharge on request.

This afternoon was spent at the Bethlem Royal Hospital, and the pathos of its approaching evacuation and demolition was appreciated. Our guests were struck with what must have been, at the time of its erection, the advanced and enlightened design of this historic building. Both the care of the patients and the research, well exemplified in Dr. Lovell's lecture in the museum, elicited the admiration of the visitors, and the genial tea-party with Dr. Porter Phillips and his Staff at the end of a warm afternoon left no manner of doubt that the visit to London would be most pleasantly remembered.

Leaving London in good time on Thursday morning, the party took the road to Littlemore, where Dr. Good demonstrated how an old building can be adapted to the needs of modern standards of clinical psychiatry. He gave us an instructive lecture on Kretschmer's anthropometric measurements, and Dr. Davies Jones related some psychological studies of considerable interest.

The influence of Dr. Good's popular out-patient clinic for nervous disorders, conducted at the Radcliffe Infirmary, on the admission-rate to this hospital was pointed out. The party observed that II of the Is wards were conducted on the open-door system, and that as far as possible the patients lived in the open air. They learned of the psychological investigations that were being carried out into the significance of dramatization, delusions and incoherence.

A pretty display of the material products of occupational therapy in the special workroom and in the wards was inspected with close attention.

At lunch the visitors were warmly welcomed by Mr. Ashhurst, the Chairman of the hospital, whose loss to the well-being of the mentally afflicted of the city and county of Oxford we now have to lament.

Dr. Good was kind enough to arrange for us to see Christ Church after an early tea, before we left Oxford for Stratford-on-Avon.

Here some who had resisted the fatigues of the long day made maiden efforts with the punt on the river, and achieved the distinction, one heard, of travelling several lengths and reaching port without losing a pole.

We left Stratford at 9.30 on Friday morning, but not before visiting the birthplace of the Bard, with whose works our visitors were remarkably conversant. "Steve" supplemented that early pilgrimage by taking us along the lane on which stood Ann Hathaway's cottage. In an hour we reached Rubery Hill. A miniature Dutch flag in the reception room quickly met the eye as we arrived and reinforced Dr. Graves's welcome. We admired the charm and elegance of the new pavilion and visited several wards of different design, but most of the morning, I think, was spent in the surgical pavilion, where sepsis is so thoroughly chastened, and the colon so effectively cleansed after the manner of Plombières.

After a very acceptable lunch we visited Hollymoor and listened to a lecture of the first importance by Dr. Graves, which included a convincing demonstration of the efficacy of seeking and treating septic foci in mental disorder. The laboratory aspect of this research was discussed by Dr. Pickworth, who exhibited some very remarkable slides and specimens.

Although the dance season had not yet commenced, Dr. Graves considerately mustered the Hospital Orchestra at short notice, and organized a dance for our visitors to witness, this kind of entertainment for patients being a novelty to them.

We left in the evening after a long, instructive and hospitable day ; and it is not unlikely that some members of the party will find their way back to this aboratory in ones or twos. 
Although the party was not generally set upon staying in the most spacious and gilded apartments, the Queen's Hotel had been selected for the night in Birmingham.

On Saturday morning, thanks to Dr. Graves's industry and foresight and to Dr. McCutcheon's readiness to receive us, it was found possible to visit the Monyhull Colony, and to see in operation those handicrafts, the beneficial influence of which has been so thoroughly and successfully explored in Dutch mental hospitals. Though the children's school was not in session, we saw this department and attempted some of the exercises devised to promote of erect locomotion among the least endowed of these little patients. We saw also the Treatment Centre and Sanatorium, the nurses' new home and several of the wards and their attractive setting before lunch, which had been advanced with great consideration for the need for an early start in the afternoon on our long run to Dolgelly.

We were fortunate enough to make Shrewsbury by tea-time. Most of this halt, however, was taken up in exposing films on the Tudor fronts.

In the course of our journey the motorists among us had learned to admire and repose in the driving skill and sense of "Steve," and were the better able to appreciate the pleasant country through which we passed along the Severn, and particularly when we later climbed up and down the stiff gradients of the Aran range and descended into the valley of the Mawddach, to reach our destination at the "Royal Ship" with most exact punctuality.

After dinner Dr. Pameijer took the piano, to the delight of all the occupants of the drawing-room. The first-aid which the instrument called for in the course of half an hour was not the result of his masterly yet delicate rendering of the Moonlight Sonata. A few minutes and a pocket screw-driver sufficed to put it on its pedals again, to yield impromptu accompaniments to the witty songs, in many tongues, by the versatile $\mathrm{Dr}$. Grervel.

Dr. Rombauts had seen Snowdon on a previous visit, and was intent on seeing again the massive peaks and rugged slopes of Carnarvonshire. Sunday morning threatened rain, and "Steve" paraded the coach in running order for a wet day. His heavy task of raising the hood was, however, not approved, and many hands assisted in replacing it in its cradle, where it could not conceal the beauties of the way. We travelled along the tortuous shore of an estuary, where the charm of the wooded valley and the incoming tide joined with the sturdy magnificence of Cader on the left and Diphwys on the right, to present an ineffaceable picture. We followed the coast of Merioneth, passing Harlech Castle, to the Pass of Aberglaslyn and the vale of Gwynant. Leaving the coach at Pen-y-Gwryd, we climbed, some more, some less, up the track towards the summit of Snowdon, in order to obtain a view of the lakes of Peris and Padarn.

Lunch was proclaimed ready at the inn on our descent, but it took half an hour to exhibit the readiness and the first course.

The necessity of securing an hour or more of daylight to make some acquaintance with the walls of Chester and its Cathedral, its ancient houses and many other features of the pre-petrol period meant that there could be no loitering by the way to contemplate the falls and glens of Bettws or the windings of the Dee.

Our quarters in Chester were a modest temperance hotel, the first view of which made the wits remark the Dutch equivalent of "Surely, here we dress." The fare, however, was distinctly good.

Dr. Menzies had warned us of the hours it would take us to reach Cheddleton from Chester, so we were up betimes and on the road before the shops opened. "Steve" made the best of the early morning, the straight roads, and our host's directions, and delivered the party at Cheddleton ahead of the time-table.

We first saw the laboratory and some thoroughly interesting demonstrations by Dr. Wilkins. A tour of the wards showed us much solid comfort for patients, and numerous ingenious devices invented by Mr. Pebworth for securing safety and hygiene without ostentation.

The wards for the training of children, including those afflicted with the later manifestations of encephalitis lethargica, provoked great admiration by their remarkable handicrafts and entertainment. We saw the question of diet treated as a matter for serious study and research; the kitchen is, indeed, a school of domestic economy with a full complement of students. Of the originality and excellence of its products we had complete and intimate evidence at the lunch 
which the Mayor of Stoke-on-Trent, the Chairman of the Visiting Committee and other members were so good as to attend.

The beauties of the grounds and gardens and the expanse and perfection of the sports ground notably impressed the visitors with the far-reaching consideration given to the welfare of the patients.

Leaving the hospital after tea we encountered some of the stiff gradients of which "Steve" had been warned, but which gave him no anxiety. Our road to Buxton rose to more than $\mathrm{I}, 500 \mathrm{ft}$. in places, and gave us a view of several aspects of those striking outcrops, the Roaches, and of the broad moors of this end of the Pennine Chain.

The party took its various ways after dinner at the Savoy Hotel, several of us going to the theatre to witness the psychopathic's misdeeds in " The Green Light." Their origin was well concealed until the play was advanced and we had a good entertainment.

The mountain mist of Tuesday morning was dense enough to postpone our start by half an hour, but it cleared sufficiently to give us some idea of the Peak, which we skirted on our way, by Glossop and the chain of reservoirs, to Wakefield. Two hours' driving in the chilly mist of the moors brought us to our destination in a ready frame of mind and state of body to appreciate the Yorkshire welcome of Prof. Bolton in providing a hot beverage the instant we reached the hospital. This consideration for the well-being of the arriving guest being a feature of Dutch hospitality, it warmly appealed to the party.

Our tour of the wards of the Acute Hospital and then of the Chronic Villas was a round of pleasant but practically empty rooms, for the open-air life is one of the outstanding therapeutic agents of the hospital, canvas shelters being provided in the gardens for meals from April to October. During the morning we saw a large group of young women in fancy costumes give a spirited display of folk-dancing on one of the lawns ; their instructors are friends of Dr. Wilson, and give a regular course of lessons in this and other recreational subjects. The hospital also has Girl Guides and Cubs.

We visited the scene of much pioneer effort in histological research where, in recent years, the contest with dysentery has been as unrelenting as it has been successful.

Lunch was a jolly meal, notwithstanding our host's merry attempts to recall one's early associations with psychiatry and the problems of our Mess. He later gave us a well-illustrated lecture on some wide variations in cephalic dimensions.

Presently we saw some of the oldest buildings for mental patients in this country, but, like the modern wards, they were empty, for the patients were taking their treatment undiluted in the open, a few with comments in the dialect of the county. In these days, when early treatment is so definitely called for, it is a sad fact that over $40 \%$ of the direct admissions are stated to have had mental disorder of more than three months' duration prior to admission ; in the case of men this percentage is 50 .

At Hatfield Hall, a manor house of rich though quiet taste, accommodation has been made for imbecile boys, whose training is largely on the lines of suitable manual occupations. Here we took tea in the garden, where the surroundings and the refreshments were very acceptable after our busy afternoon.

Hospitality at Wakefield extended twice round the clock, and after travelling a week in England our visitors arrived at an unquestionable occasion " to dress." At 7 o'clock we attended the Cinema in the hospital which, this week, had been very kindly arranged for the night of our stay. The programme, which included "Beau Sabreur," was a thoroughly enjoyable one, and we afterwards went below to supper-a no less enjoyable proceeding. At various hours we retired to our quarters in the hospital or its annexes.

On Wednesday morning we set off, after a crowded and memorable visit, to the Rampton State Institution, near Retford, where the new villas, the industries and the management of the problems associated with cases brought here because of their dangerous character, all kindled the warmest admiration of our Dutch colleagues. At the lunch and tea, when they were the guests of the Board of Control, they had many questions to ask, and they received much detailed information, including dietary tables of a comprehensive kind.

That night we stayed at Grantham at "The George" and were comfortably housed. Our main entertainment, after dinner, was provided by the benign 
caricatures of the party by the pencil of Dr. Grervel, who also gave us further items from his store of verse.

Accustomed now to early morning departures the party was well on its way south by 9 o'clock on Thursday. We left the Great North Road at Stamford, travelling slowly through this, one of England's oldest towns. Then to the south-west, we passed through a country of pleasing undulations, of grey villages each with its slender spire.

Our objective this morning was St. Andrew's Hospital, Northampton, a drive of about sixty miles, at the end of which the stimulating greeting of Dr. Rambaut was particularly welcome. We spent the morning in the spacious rooms of the hospital of 1836 , and in the new Home for nurses, now building; we also visited the Chapel, a rare gem of singular beauty.

The intimate acquaintance which all our visitors displayed with our language was a matter of surprise to all who met them; nor were they at any loss for the apt phrase when expressing the gratitude of the party to their hosts in the more exacting manner of a luncheon speech. At St. Andrew's, his name being akin to that of our host, Dr. Rombauts, of Santpoort, was chosen to respond to Dr. Rambaut's toast, "The King of England and the Queen of Holland." He called upon his fellow travellers to sing "Lang zullen ze leven," the equivalent of "For he's a jolly good fellow," and they did.

Our visit would have been both instructive and noteworthy had it gone no further than the premises already visited, but our subsequent tour of the new Wantage Hospital rendered the day eventful with the graphic and concentrated exhibit of so many means for the exploration and remedy of mental illness. It would be indeed a most potent and evil spirit that could resist all the scourings, without and within, provided by the chambers of Turkey and Russia, the douches of Scotland and Aix, by the searchings of the $\mathrm{X}$-ray and sun-ray, available in the blackest night, or by currents galvanic and faradic.

The Pathological Laboratories for bio-chemical, histological and bacteriological investigations leave no path untrodden in research for which this remarkable building has been erected. Lastly we came to those important quarters in which the patient passes his time of investigation and treatment. Whatever the laboratory findings ultimately indicate, he is assured at once of two remedies without stint or delay - fresh air and sunlight under conditions of repose and quiet.

This is a hospital where the first consideration has been the needs of the patient, and the last the academic demands of architectural magnificence; with all its scientific apparatus and the numerous contrivances for the most thorough ablution, it is, in truth, a refreshing and homely retreat.

Our lodging that night was at the "Blue Boar" in Cambridge, and no little day. light being required for the better acquaintance of the town, we took our leave of Dr. and Mrs. Rambaut soon after tea.

Our wanderings among the venerable buildings of Cambridge continued till dusk, and we had to examine the interior of the Round Church by palpation without inspection !

This was our last night as an entire party, for although about half the number remained for Friday night in Colchester, the others went their respective ways during Friday.

There were evident signs of regret on leaving Cambridge.

The last day was devoted to the Royal Eastern Counties Institution, or, more exactly, to as many of its branches as we could visit in a vigorous day. We met Dr. Turner at Halstead, where the Guides' School received us with a greeting which would have done credit to a Signal Company. We saw the classes at work and at play, and girls of all sizes in drill, dance and pantomime. This industrious little community does much towards its own maintenance, and had made the many dainty things that were worn in the numerous scenes so nimbly represented.

It was on our journey from Halstead to Colchester, after some yoo miles of touring, that the first shower compelled us to use the hood of the coach.

In the town we visited the two houses for boys, two groups with very unequal mental endowment, of which however the best use is being made, as may be seen by the products of their hands and the delight with which they perform their physical exercises. Dr. Turner next took us to the headquarters of the Institution, where the boys' capital band entertained us while we enjoyed an ample lunch. 
In these premises are some of the most pronounced cases of deficiency, both mental and physical; they all, however, make a very successful claim for devoted attention. It was a great change to pass to the business-like workshops, where no patient toils with his hands who can control a loom or a machine. The contrast was still more striking when we saw the gymnastic display, the big lads somersaulting not only over the wooden horse, but over another boy kneeling on it. A dance in the Concert Hall completed the rapid survey of some of the activities in these buildings, the second oldest foundation of its kind in England, and we passed on to a late development, the Hostel at Lexden, from which girls go out daily into domestic service.

After tea in this pleasant residence five of us left the main company and "Steve" brought us back to London; the others left for Holland on Saturday morning, September 21 .

From the first days of the tour our guests were greatly impressed with the structural excellence and comfort of the hospitals which they visited, and with the wealth of care bestowed on the patients as well as the thoughtful provision for the amelioration of their enforced stav; but having in mind the intensity and success of the promotion of occupational handicrafts among the noisy, degraded and demented patients of their own hospitals in Holland, it was clear that their frequent view, here, in gardens and wards, of patients reposing in unoccupied leisure made them wonder sadly if their friends in England had not heard of the work-therapy gospel of Simon of Gütersloh, to which some reference was made in the January number of this Journal for 1929.

From long letters of appreciation and gratitude which I received from Dr. Stuurman and Dr. Pameijer, one realized that our visitors had been keenly observant of every detail of administration and structure, of research and treatment. One visitor had inquired where the psychological research was carried out; I told him, and added that we often called psychiatry "psychological medicine." For the comfort of the Ministry of Transport, I must not conceal their high regard for " the magnificent roads everywhere in England."

The statutory provision for dealing with high-grade mental defectives and the admirable means which they saw for meeting the needs of this group gained the entire commendation of our colleagues, who have no legal powers in Holland for protecting the feeble-minded, or for accommodating them even in " open " wards, otherwise than in the mental hospitals. I gathered that the personal and therapeutic attention given to our patients' physical, mental and social needs made a deep impression which will at no distant date be reflected in the hospitals of the Netherlands, for Dr. Stuurman writes from Leiden: "We have all seen and heard many things which we shall try to imitate here."

A. E. E.

\section{PRESENTATION.}

Prof. G. M. Robertson, of the Chair of Psychiatry in the University of Edinburgh, was recently presented with his portrait (painted by $\mathbf{H}$. J. Gunn) by the managers of the Royal Edinburgh Hospital, to mark their appreciation of his many rears' service as Physician Superintendent of the Hospital.

\section{NOTICES BY THE HONORARY LIBRARIAN.}

Principal books recently added to the Library : Psychologie du Socialisme. Gustave le Bon. 1917. Problémes généraux d'heredité psychologique. Poyer. 1921. De l'inconscient au Conscient. Geley. 1929. La Psychologie inconnue. Boirac. 1912. La méthode Psychanalytique. De Saussure. 1922.

Additional books presented by Dr. Whitwell : Origins of Art, a Psychological Enquiry. Hirn Yrjö. 1900. Herbartian Psychology. Adams (undated). Applied Eugenics. Papenhoe and Johnson. 1920. The Psychology of Marriage. Gallichan. 1917. St. Audry's Hospital Reports (bound). 1898-1924. 